
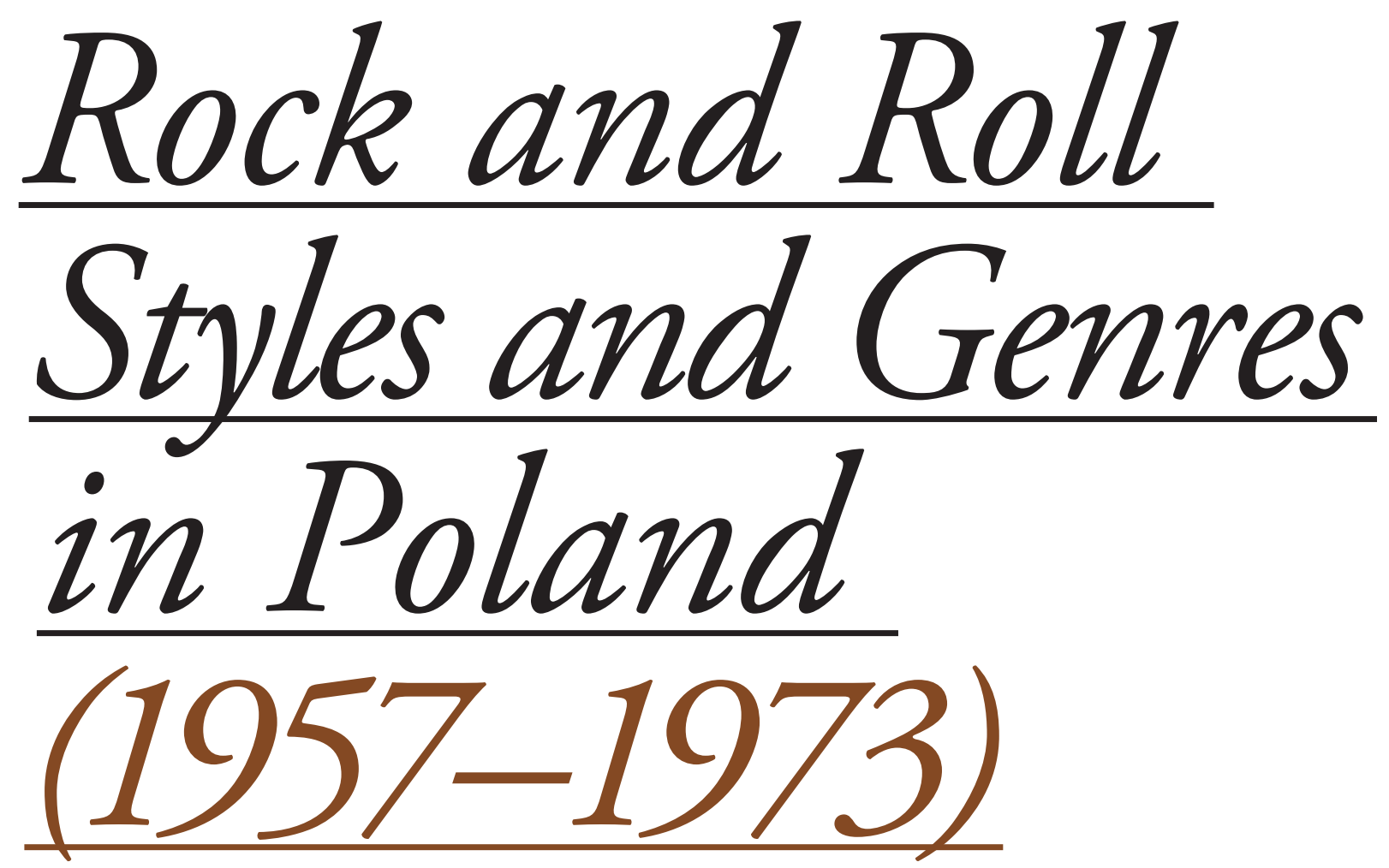

\title{
MARIUSZ GRADOWSKI
}

University of Warsaw

Email: mariusz.gradowski@uw.edu.pl

This publication has been co-financed from the funds of the Vice-Chancellor of the University of Warsaw. This publication has been co-financed from the funds of the Ministry of Science and Higher Education. 
Musicology Today • Vol. $13 \bullet 2016$

DOI: 10.1515/muso-2016-0003

\section{$\underline{\text { ABSTRACT }}$}

This paper describes the process of establishing rock and roll styles and genres (as defined by Allan F. Moore) in Polish musical culture. My Ph.D. research has revealed three phases in this process. Phase 1: imitation (1957-1962), phase 2: Polonisation (1962-1967) and phase 3: artistic re-interpretation (1967-1973). I present the detailed characteristics of each phase (i.e. their socio-political context, the phenomenon of cover versions, the fusion of rock and roll with local folk music, the development of original artistic language) as well as providing musical examples (mostly from Czesław Niemen's recordings, which remain one of the most interesting examples of Polish popular music).

Keywords: Style, genre, Polish popular music, rock, pop, big-beat, Czesław Niemen

$\underline{1 .}$

Polish rock and rock and roll music is usually discussed from the perspective of sociological, historical, culture and literary studies, to mention only the well-known pioneering publications by Jerzy Wertenstein-Żuławski, ${ }^{1}$ Przemysław Zieliński, ${ }^{2}$ Tomasz Toborek ${ }^{3}$ and Anna Idzikowska-Czubaj, ${ }^{4}$ as well as the group of researchers attending the Unisono Conferences in Tułowice. ${ }^{5}$ I have taken up the task of complementing this important research from the perspective of my own discipline, which for a long time admittedly considered the (broadly

1 Cf. J. Wertenstein-Żuławski, (1990). To tylko rock and roll! [It's Only Rock'n'Roll]. Warsaw: Wyd. ZAKR.

2 Cf. P. Zieliński, (2005). Scena rockowa w PRL. Historia, organizacja, znaczenie [The Rock Scene in the Polish People's Republic]. Warsaw: Wydawnictwo Trio.

3 Cf. T. Toborek, (2002). Początki big-beatu w prasie PRL [The Beginnings of Big-Beat in the Press of Communist Poland], Biuletyn Instytutu Pamięci Narodowej [Bulletin of the Institute of National Remembrance]. No. 10 (21), pp. 58-63. Idem, (2010). Niezależna muzyka rockowa [The Independent Rock Scene]. Łódź: Wyd. IPN.

4 Cf. A. Idzikowska-Czubaj, (2011). Rock w PRL-u. O paradoksach wspótistnienia [Rock in the Polish People's Republic. Paradoxes of Coexistence]. Poznań: Wyd. Poznańskie.

5 The conferences "Unisono w wielogłosie" (approximate translation: "With One Voice - With Many Voices"; originally as "Unisono na pomieszane języki" - "With One Voice after the Confusion of Tongues") have been held since 2009 in Tułowice (formerly Tillowitz) near Opole by the Institute of Slavic Studies, Opole University. Five volumes of conference proceedings have been published, while the sixth is in print. conceived) subject of popular music as only marginal. My research concerned the stylistic and generic features of Polish big-beat and the process of reception of the Western rock and roll music in Poland. The results have been described in my dissertation entitled The Styles and Genres of Polish Teenage Music in 1957-1973. ${ }^{6}$

Before proceeding to a discussion of the topic, let me define the key terms. "Big-beat" will be understood here as a widespread eclectic trend in Polish music from the late 1950 s to the early 1970s, which encompassed a wide range of styles and genres originating mostly in rock and roll. Importantly, I do not treat big-beat as either a style or a genre in itself. This is a consequence, among others, of accepting the British musicologist Allan F. Moore's definitions of the terms "style" and "genre". You may be familiar with Allan Moore's claim that instead of the traditional hierarchical relation of style to genre (which he exemplifies with the works of Leonard B. Meyer, Franco Fabbri and Roy Shuker), we can describe genres and styles in popular music by placing them in a coordinate system which represents the positions of various musical phenomena. ${ }^{7}$ In Moore's view, the terms "style" and "genre" refer to two aspects of the same music. Style refers to sound and can be described by means of techniques of music analysis. Genre is extra-musical and is best described by such related disciplines as sociology, psychology and history. From this perspective, the $1950 \mathrm{~s}$ rock and roll can be considered as a style (for instance, when we point to the prevalence of the 4/4 time signature, the frequent use of 12-bar blues and stanza-and-refrain patterns, to characteristic arrangements including a tenor sax part, the central role of electric lead guitar and rhythm guitar, as well as the dominance of backbeat on the level of rhythm), but also as a genre (owing to its rooting in teenage culture, which determined its

6 M. Gradowski, (2015). Style i gatunki polskiej muzyki młodzieżowej w latach 1957-1973 [The Styles and Genres of Polish Teenage Music in 1957-1973], PhD dissertation. Warsaw: University of Warsaw.

7 This summary of the views of Allan F. Moore is based on his articles: idem, (2002). Categorical Conventions in Music Discourse: Style and Genre, Music \& Letters. Vol. 82, No. 3, pp. 432-442; idem, (1998). Issues of Style, Genre, and Idiolect in Rock Style [online:] www.allanfmoore.org.uk, <http://www. allanfmoore.org.uk/questionstyle.pdf $>$, [accessed on $1^{\text {st }}$ February 2016]; idem, (2009). Style and Genre as a Mode of Aesthetics, [online:] www.allanfmoore.org.uk, <http://www.allanfmoore.org. uk/styleaesth.pdf $>$, [accessed on $1^{\text {st }}$ February 2016]. 
differentiation from earlier popular music, its social functions and its ethos - related to a more or less actual rebellion, as well as its visual aspects - the characteristic image and behaviour on the stage). Allan F. Moore does not recommend any umbrella terms for a comprehensive style-and-genre classification. In my descriptions I will therefore use the musicological term "idiom": the "idiom of rock and roll" refers to a comprehensive view of the musical phenomenon, considered from both the stylistic and the generic perspectives.

My analysis of the process of reception of Western influences in Poland took as its starting point a model proposed by Edward Larkey, an American scholar focusing on popular music in German-speaking countries. Larkey distinguishes four distinct historical phases:

1. the phase of the consumption of new musical culture by a new audience;

2. the phase of local performers imitating the new solutions;

3. the phase of the de-Anglicisation of the imported music, of including new musical elements in the local bands' repertoires, and of replacing English lyrics with standard German;

4. the phase of the re-ethnification or re-ethnicisation of the new styles as independent hubs of creativity and innovation, and the movement against previously accepted traditions, now replaced by local dialects and by musical elements derived from local traditions. ${ }^{8}$

Commentators of Larkey's thought, such as Motti Regev, suggested the possibility of applying his model to the study of reception in other countries ${ }^{9}$. However, already initial consideration suggests that Larkey's model only has a limited application in the Polish context, especially with respect to purely musical criteria. This initial assessment has been confirmed in my research. Some of the phenomena pointed out by Larkey (such as the "re-ethnification") were not represented in Poland, while others, such as the consumption phase, had a completely different character. For these reasons, I proposed a different model to describe the process of

8 Cf. E. Larkey, (1992). Austropop: Popular Music and National Identity in Austria, Popular Music. Vol. 11, No. 2: „A Changing Europe", pp. 151-185.; idem, (1993). Pungent Sounds: Constructing Identity with Popular Music in Austria. New YorkBern-Berlin: Peter Lang.

9 Cf. e.g. M. Regev, (1995). Review: Pungent Sounds: Constructing Identity with Popular Music in Austria by Edward Larkey, Popular Music. Vol. 14, No. 2, pp. 275-276. reception of rock and roll and of music stemming from rock and roll in Poland. It is a model which, I believe, captures and explains a crucial process of transformation.

In the mid-1950s, rock and roll was virtually unknown in Poland. In the late 1960s and early 1970s, it was commonly known and popular. At first, few musicians performed rock and roll, but also this changed quite quickly and a cautious estimate of 1969 speaks of twelve thousand bands playing this kind of music. The music itself had also significantly changed by that time. ${ }^{10}$ One of the first Polish rock and roll songs, written in 1957 , was about... a cat playing cat music:

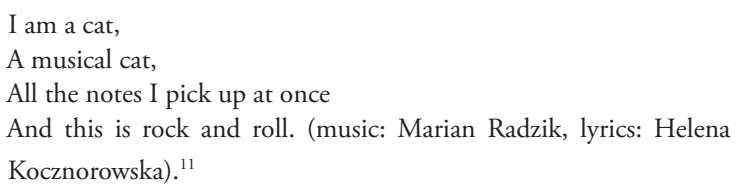

(By the way, since this song appeared in print, it was most likely also performed, but no recordings of it exist. Considering the naïve, childish lyrics and the rather uninspired music, it is not hard to guess why.)

Just over a dozen years later, Czesław Niemen presented an extremely moving setting of a text by one of Poland's greatest Romantic poets of the $19^{\text {th }}$ century, Cyprian Kamil Norwid:

\footnotetext{
The Earth stands still - and the depth of time,

And all those who are still alive,

Though not a bone shall remain on them,

There will be people, as there are today... ${ }^{12}$
}

Between the trivial occasional nature of $A$ Cat on the Keyboard and the grave vision of human transience in Niemen's Puppets, the process of the reception of rock and roll in Poland had already largely taken place, giving

10 Cf. G. Michalski, W. Panek, (1969). Polski big-beat [The Polish Big-Beat], Ruch Muzyczny. No. 11, p. 16.

11 Cf. Kot na klawiszach: rock and roll [A Cat on the Keyboard: A Rock'n'Roll] (music: Marian Radzik, words: Halina Kocznorowska) [in:] Zeszyt $n r 119$ [pieces for 3 saxophones, trumpet, 3 violins, accordion/piano, guitar, double-bass and percussion (instrumental parts)], in the series "Biblioteka orkiestr tanecznych" ["Dance Band Collection"], (1959). Cracow: PWM

12 C. Norwid, (1971-1976). Marionetki [Puppets]. In: idem, Pisma wszystkie [Collected Writings]. Collected, edited, with an introduction and footnotes by J.W. Gomulicki. Vol. 1. Warsaw: PIW, p. 345; Grupa Niemen, LP Niemen, Vol. 2. Muza SXL 0895, 6, 1972/73; Grupa Niemen, CD Marionetki, in the series Niemen od początku II [Niemen from the Beginning II]. PRCD 337, 2003. 
this music its local shape as a mature language of artistic expression.

I have distinguished three phases in the process of reception. Rather than being conceived as separate stages, these three phases form a continuum of gradual transformations, though each phase had its characteristic dominant features. For instance, the key features of phases two and three already appeared in phase one, but were still of minor importance at that stage. On the other hand, the qualities of phase one did not quite disappear in phases two and three, but were rather pushed to the margin of mainstream style-and-genre transformations. For the purposes of the present paper, I will illustrate the three phases with examples from the music of the already mentioned Czesław Niemen.

\section{$\underline{2}$.}

The first phase in my analysis is that of direct imitation (1957-1963), with which the process of reception began. It was characterised by the emulation of a rock and roll idiom more or less akin to Western models. Apart from imitation, another feature of this phase is the complex relation between jazz and rock and roll. One example of this, important for the reception of Western music in Poland, is William "Big Bill” Ramsey's concert at the Jazz Festival in Sopot (1957), where Ramsey played mainly blues-related music (such as Louis Jordan's Caldonia and the traditional Goin'To Chicago Blues, John Henry, Frankie And Johnny, St. James Infirmary) at a jazz festival, but all the same he was classified as a rock and roll musician. ${ }^{13}$ This complex relation is also evident when we begin to search for the first Polish examples of rock and roll music. The results of such a search will depend on whether we analyse the stylistic or the generic qualities of the music, or its overall idiom. Depending then on the accepted criteria, we could point to music composed and recorded by Jan Walasek (with regard to style), or to the songs In Arizona (music: Wiesław Machan, lyrics: Janusz Odrowąż Pieniążek, sung by Zbigniew Kurytcz), Dance and Sing Rock'n'Roll (music: Romuald Żyliński, lyrics: Kazimierz Winkler, performed by Czejanda Choir) ${ }^{14}$ and the most likely never recorded (though printed in the same

13 Cf. F. Walicki, (2000). Szukaj, burz, buduj [SBB - Seek, Break Up, Build Anew], $2^{\text {nd }}$ extended ed., Warsaw: T.R.Z. / Wojciech Trzciński, p. 96.

14 Tańcz i śpiewaj rock and roll: na głos z fortepianem [Dance and Sing Rock'n'Roll, for voice and piano], in the series: "We Sing and Dance" Collection, (1957). Cracow: PWM. volume as In Arizona) songs entitled Mistakes and One, Two, Go... ${ }^{15}$ (with regard to distinct features of genre). From the point of view of musical idiom, we could also consider the songs recorded for the Polish Radio by the Rhythm and Blues ensemble ${ }^{16}$ as pioneering examples of Polish rock and roll.

The first phase, as represented in Niemen's output consists, primarily of recordings with the NiebieskoCzarni band, with which he made his debut in 1962. In that period he performed popular twists as well as hits from Ray Charles's repertoire. Notably, however, apart from music of rock and roll provenience, Niemen also sang popular pop songs, which suggests that though rock and roll captured the imagination of the young Polish audience in the late 60's / early 70's, this fascination did not preclude the possibility of, and interest in, the performance of non-rock repertoire. The boundary was fluid. Individual pieces were often discussed in wider than the merely stylistic categories, and labelled as "Western" or "teenage" music.

The second phase - that of Polonisation (1963-1967) was characterised by Polonising the Anglo-Saxon models of rock and roll. It was in this phase that musicians put forward original Polish style-and-genre ideas which began to differentiate Polish teenage music from its Western equivalents. Most significant for this Polonisation process were: the appearance of songs with Polish lyrics, references to Polish folk music (or to music then considered as folk, such as the compositions of Tadeusz Sygietyński and Stanisław Hadyna), as well as the growing popularity of instrumental music without Polish-language content (which was, in my opinion, a defensive reaction on the part of those musicians who wished to come as close to Western style as possible, but were prevented from singing in English by the state's official cultural policies). An important aspect of the Polonisation phase was the institutionalisation of teenage music, evident e.g. in the flourishing of concert and festival life and in the growing presence of big-beat in the media.

Niemen's output includes numerous pieces that exemplify the qualities of the second phase very well. This concerns, first and foremost, songs of folk and quasi-folk provenience such as What Time Is It, Mr Bear? and Mother, Our Mother. It should be stressed, however, that Czesław Niemen was unique in that he relatively

15 Cf. 3 x rock and roll: na fortepian z tekstem podłożonym [3 Times Rock'n'Roll, for piano with text underlaid, pieces for solo voice and piano], (1957). Warsaw: Znak.

16 Some of these were released on the CD Bogusław Wyrobek. Legenda, Muza PNCD 340, 2000. 
quickly began to write his own original songs, whose appearance and popularity already heralded the third phase of reception. I believe one could demonstrate that Niemen and The Beatles had similar significance for the formation of original rock and roll repertoire in their respective languages. Just as the popularity of McCartney and Lennon's productions encouraged other performers to write their own songs, so also Niemen's popularity (even though he rarely wrote his own lyrics at first) inspired other Polish musicians. In later years, that influence grew even stronger. Niemen began to sing the classics of Polish poetry, and then - started writing his own, high quality lyrics. In a culture space occupied by professional songwriters on the one hand and mostly unattractive amateur productions on the other, Niemen's songs definitely stood out. This is why we can treat the success of his Strange Is This World, sometimes interpreted as a protest-song, as the starting point of phase three in the reception of rock and roll in Poland.

Phase three - that of creative reinterpretation - was characterised by more or less successful attempts at transplanting the main qualities of Western style-andgenre repertoire onto the Polish soil, while at the same time filling these forms with suitable local content. In this phase, Polish teenage music in many cases reached artistic maturity, reflected in its influence on later generations of musicians. After the period of apprenticeship in the first two phases, of learning the Western rock and roll-based musical language, and after the more or less successful attempts to combine Western music with Polish-language lyrics, phase three produced works that in many respects could match the Western music of that period; works that certainly inspired Polish culture and became its living points of reference.

In Niemen's music, as I have already suggested, the breakthrough came with the song Strange Is This World, or, more generally, with the eponymous album released in 1967. In the following years, Niemen's music developed with lightning speed - from mature British Merseybeat (exemplified by The Beatles' Rubber Soul and Revolver) on his LP Strange Is This World, to increasing inspiration from Otis Redding and James Brown on his soul albums Success and Do You Still Remember Me, to elements of progressive rock on the LP Niemen Enigmatic, to hard rock on the so-called Red Album (Ungrateful Man I Am), to jazz rock with elements of free jazz, improvised avant-garde and poetic song in Puppets. The pace of these transformations can well be illustrated with Niemen's attempts to conquer the Italian market: in several months, he was transformed from a performer of songs by The Rolling Stones, James Brown and Blood, Sweat and Tears in local clubs into an artist who ignored the popular taste and treated his audience to such works as the Threnody In The Memory Of Bem, much to the confusion of the accompanying dancers, and with long sax improvisations by Zbigniew Namysłowski.

\section{3.}

My research has allowed me to formulate several conclusions. Firstly, despite the socio-political and economic situation in the Polish People's Republic, and the resulting problems with access to recordings, sheet music and musical instruments, the reception of popular Western music was exceptionally fast. The distance between Western and Polish music productions also diminished quite quickly. While in 1957 rock and roll was still something exotic and probably misunderstood in Poland, ten years later it had already produced many original compositions, not only winning a prominent place in Polish popular music, but also entering into a dialogue with the contemporary achievements of British and American music. This is true, for instance, of the songs Run, Run Away by Skaldowie and What Happened to the Flowers by Breakout. The list of Czesław Niemen's compositions that can rival the top achievements of Western rock is particularly impressive and includes the Threnody In The Memory Of Bem, Native Flowers, Puppets, A Pilgrim, Ungrateful Man I Am, Italiam, Italiam, and many others.

Secondly, research into the process of reception has demonstrated that in the course of adaptation to Polish conditions, Polish rock and roll music diverged from its Western models - mostly with respect to genre characteristics. The style of a given musical idiom can be adopted and imitated quite faithfully, but the qualities of the genre (determined by cultural, historical, and social factors) are usually modified in the process of reception to suit local contexts. We can follow Allan F. Moore in claiming that the new musical qualities produced in this process, even if they are not widely accepted (and therefore functioning as a defective variant of the adopted idiom), may still develop into an original musical language characteristic of the given performer, and, given the right conditions, may also form an original local idiom.

Thirdly, my research has revealed those qualities of Polish big-beat that in my opinion differentiate it from Western models. These include close and unique links between Polish big-beat and jazz. Jazz music and musicians greatly contributed to improving the artistic quality of Polish big-beat by co-creating major musical 
works in phase three - that of creative reinterpretation. An excellent example of this is Czesław Niemen's collaboration with saxophonists Zbigniew Namysłowski and Michał Urbaniak (a later stage partner of Miles Davis), percussionist Czesław Bartkowski, pianist Jacek Mikuła and free-jazz trumpeter Andrzej Przybielski. Echoes of folk music also add to the originality of Polish big-beat, though admittedly such folk references were not always artistically very successful. The social and professional context of Polish teenage music in 1957-1973 also meant that the opposition between (counter-cultural, rebellious, independent) rock and (conformist) pop commissioning material from professional composers and songwriters seems irrelevant in the Polish context.

\section{$\underline{\text { SOURCES }}$}

$3 x$ rock and roll: na fortepian $z$ tekstem podtozionym [3 Times Rock'n'Roll, for Piano with Text Underlaid, Pieces for Solo Voice and Piano], (1957). Warsaw: Znak. Bogustaw Wyrobek. Legenda, (2000). Muza PNCD 340.

Grupa Niemen, (1972/73). LP Niemen, Vol. 2. Muza SXL 0895, 6.

Grupa Niemen, (2003). CD Marionetki, series Niemen od poczatku II [Niemen from the Beginning II]. PRCD 337.

Kot na klawiszach: rock and roll [A Cat on the Keyboard: A Rock'n'Roll], (1959). In: Zeszyt nr 119, series "Biblioteka orkiestr tanecznych" ["Dance Band Collection"]. Cracow: PWM.

Norwid, C. (1971-1976). Marionetki [Puppets]. In: idem, Pisma wszystkie [Collected Writings]. Collected, edited, with an introduction and footnotes by J.W. Gomulicki. Vol. 1 (p. 345). Warsaw: PIW.

Tańcz i śpiewaj rock and roll: na gtos z fortepianem [Dance and Sing Rock'n'Roll, for voice and piano], (1957). Series: "We Sing and Dance" Collection. Cracow: PWM.

\section{$\underline{\text { REFERENCES }}$}

Gradowski, M. (2015). Style i gatunki polskiej muzyki mtodzieżowej $w$ latach 1957-1973 [The Styles and Genres of Polish Teenage Music in 1957-1973], PhD dissertation. Warsaw: University of Warsaw.

Idzikowska-Czubaj, A. (2011). Rockw PRL-u. Oparadoksach wspótistnienia [Rock in the Polish People's Republic. Paradoxes of Coexistence]. Poznań: Wyd. Poznańskie.
Larkey, E. (1992). Austropop: Popular Music and National Identity in Austria, Popular Music. Vol. 11, No. 2: „A Changing Europe”, pp. 151-185.

Larkey, E. (1993). Pungent Sounds: Constructing Identity with Popular Music in Austria. New York-Bern-Berlin: Peter Lang.

Michalski, D. (2009). Czestaw Niemen. Czy go jeszcze pamiętasz? [Czestaw Niemen. Do You Still Remember Him?]. Warszawa: Wydawnictwo MG.

Michalski, G., Panek, W. (1969). Polski big-beat [The Polish Big-Beat], Ruch Muzyczny. No. 11, p. 15-17.

Moore, Allan F. (1998). Issues of Style, Genre, and Idiolect in Rock Style. Text available on-line: http://www. allanfmoore.org.uk/questionstyle.pdf [accessed on $1^{\text {st }}$ February 2016].

Moore, Allan F. (2002). Categorical Conventions in Music Discourse: Style and Genre, Music \& Letters. Vol. 82, No. 3, pp. 432-442.

Moore, Allan F. (2009). Style and Genre as a Mode of Aesthetics. Text available on-line: http://www. allanfmoore.org.uk/styleaesth.pdf [accessed on $1^{\text {st }}$ February 2016].

Radoszewski, R. (2004). Czestaw Niemen. Kiedy się dziwić przestane... Monografia artystyczna [Czestaw Niemen. When Will I Stop Wondering... An Artistic Monograph]. Warsaw: Iskry

Regev, M. (1995). Review: Pungent Sounds: Constructing Identity with Popular Music in Austria by Edward Larkey, Popular Music. Vol. 14, No. 2, pp. 275-276.

Toborek, T. (2002). Początki big-beatu w prasie PRL [The Beginnings of Big-Beat in the Press of Communist Poland], Biuletyn Instytutu Pamięci Narodowej [Bulletin of the Institute of National Remembrance]. No. 10 (21), pp. 58-63.

Toborek, T. (2010). Niezależna muzyka rockowa [The Independent Rock Scene]. Łódź: Wyd. IPN.

Walicki, F. (2000). Szukaj, burz, buduj [SBB - Seek, Break $U$, Build Anew], $2^{\text {nd }}$ extended ed., Warsaw: T.R.Z. I Wojciech Trzciński.

Wertenstein-Żuławski, J. (1990). To tylko rock and roll! [It's Only Rock'n'Roll]. Warsaw: Wyd. ZAKR.

Zieliński, P. (2005). Scena rockowa $w$ PRL. Historia, organizacja, znaczenie [The Rock Scene in the Polish People's Republic]. Warsaw: Wydawnictwo Trio.

Mariusz Gradowski (1979), studied anthropology of culture and culture studies at the Institute of Polish Culture under the supervision of Prof. Leszek Kolankiewicz, PhD Hab. (The Man, The Sacred and The Art of Sound, MA, 2004) and musicology at the Faculty of History of the University of Warsaw under the supervision of Prof. Sławomira 
Żerańska-Kominek, PhD Hab. (The Work of The Doors, MA, 2005). In 2005, as a lecturer, he joined the Division of Systematic Musicology at the Institute of Musicology, University of Warsaw. After successful defence of his PhD dissertation (The Styles and Genres of Polish Teenage Music in 1957-1973, PhD, 2015) he was offered a position as Assistant Professor. His scientific interests include the reception of rock and roll styles and genres in Polish musical culture, history of rock, history of Polish jazz, theory of film music and anthropology of music. He is also a radio journalist. 